\title{
Clinically Compare the Efficacy of n-butyl Cyanoacrylate and Vicryl Suture in Intra Oral Wound Closure-An Invivo Study
}

\author{
Dr Murugan. $\mathbf{K}^{1}$, Dr Thinakar Babu .A $\mathbf{A}^{2}$ \\ ${ }^{1}$ Maxillofacial Surgeon, Revathi Medical Center,Tirupur, India \\ ${ }^{2}$ Senior Lecturer, The TN Dr MGR Medical University, Chennai, Tamilnadu, India
}

\begin{abstract}
Background: Intra oral mucosal incision is the common procedure for removal of impacted tooth, removal of teeth, alveoloplasty procedure and removal of any pathology in maxilla and mandible. Usually intra oral mucosal incision closed with vicryl suture material. Usually incision is closed with suture but patient has more apprehension with sutures, so we need alternative procedure like tissue adhesive for closure of intra oral mucosal incision. Cyanoacrylate reduces the patient apprehension as well as good biocompatibility material to close the intra oral mucosal incision. Objectives: The present study was undertaken to compare the efficacy of $N$ Butyl 2 cyanoacrylate and vicryl suture in intra oral wound closure. This study also investigate pain and wound dehiscence in closure of intra oral mucosal incision. Methods: Fifty patients were included in this study. Vicryl suture and $N$ Butyl 2 cyanoacrylate is used in patients. Intra oral mucosal incision placed for the purpose of extraction and alveoloplasty procedures. After the required procedure has been performed, closure of wound is achieved with flap. After flap is approximated passively wound is closed with vicryl suture on one side and on other side wound is closed with $N$ Butyl 2 cyanoacrylate. Then the patient is recalled on1st, 3rd, 5th and 7thpost operative day for evaluation of pain and wound dehiscence at surgical site. Results: The results showed that there was no statistically significant difference between suture and cyanoacrylate for occurrences of pain and wound dehience in closure of oral mucosal incision. HoweverThe $N$ butyl 2 cyanoacrylate has the advantage of reduce patient apprehension and patient compliance. Conclusion: It may be concluded that efficacy of closure of passively approximated intra oral mucosal incision is same for vicryl suture and $N$ Butyl 2 cyanoacrylate. But, $n$ Butyl 2 cyanoacrylate has the advantage of haemostatic, bacteriostatic properties and time consuming also less. Moreover it reduces patient apprehension and better patient compliance than the incision closure with the vicryl suture material.
\end{abstract}

Keywords: adhesive suture, paste suture, n-butyl cyanoacrylate

\section{Introduction}

Wound closure is assisted by usage of appropriate suturing technique and suture material in intra oral and general surgical procedures and aimed at maintaining form, function and aesthetics of surgical site. ${ }^{1}$

Suturing the wound reduced the inflammatory cells accumulation around the suture material and it leads to faster healing. ${ }^{2}$ In Diabetic and immunocompromised patient tissue response produced for the suture material gains importance. $^{3}$

Healing by primary intension requires proper approximation of wound edges, complications of healing after surgery may result because of any of the following reasons or a combination of them,

1) Improper preoperative assessment

2) Traumatic surgery

3) Poor post operative care

Generally infection or reinfection in the wound hinders the healing process. This is the most important aspects in healing of intra oral wounds. Increased chance of intra oral wound infection is due to presence of plaque and food debris in the oral cavity, so intra oral surgical procedures are more prone to infections. To minimize the post operative infection in the intra oral wound need a aseptic environment and proper handling of the soft tissue and hard tissue structures.
Properly assessed and planned surgery need immobilization of healing tissue and this can be performed by using appropriate suturing technique and suture material or tissue adhesive. Surgical Wounds are closed with the sutures from the time of immemorial. Though advanced suturing techniques and suture materials are present, fistulations, rail road track scars and suture granulomas remain as disadvantages for sutures. It also has disadvantages of pricking the normal parenchymal tissue and inflammatory tissues while suturing of wound. Because of capillary action of suture materials, there is increased chance of infection or reinfection. Suturing technique increases the time of surgical procedure and anesthesia. The surgeon should exert control force during suturing otherwise the excess forces may lead to the tension in the suture and result in tearing or necrosis at wound margin. Loose suturing causes gaping between the wound edges, so it may lead to increase the chance of infection and delay the healing process. While suturing accidental needle prick causes increased chance of transmission of disease like AIDS and Hepatitis to the surgeon. Because of the iatrogenic complication of suturing, alternative technique like tissue adhesive emerged to close the wound margins. Tissue adhesive materials completely eliminate the needle prick injury and tearing of the wound margin while closing the wound margins. So tissue adhesives are becoming popular. Because of the increased necessity of tissue adhesive, the effectiveness, advantages and disadvantages of the tissue adhesive was compared over traditional method of wound closure of suture. 


\section{International Journal of Science and Research (IJSR) \\ ISSN (Online): 2319-7064 \\ Index Copernicus Value (2015): 78.96 | Impact Factor (2015): 6.391}

Property of ideal tissue adhesive for intra oral wound closure:

Stability,

It should undergo complete polymerization in presence of moisture, (saliva, blood and water)

It should have adequate working time to apply,

It should cover the optimum area,

During polymerization it should not exert more heat to the tissue,

It should be biodegradable,

It should be easy to use,

It should not be carcinogenic,

Complete Wettability.

Among the materials in tissue adhesive, $\mathrm{N}$ Butyl 2 cyanoacrylate fulfills most of the ideal properties of tissue adhesives.

Adhesive property of cyanoacrylate was discovered in 1959. Initial tissue adhesives were in alkyl form and ethyl form. These tissue adhesive were discontinued because of their toxic effects on the tissue. But long molecular chain of $\mathrm{N}$ Butyl 2 cyanoacrylate is not toxic and it has the advantages achieving haemostasis, bacteriostatic properties and exhibit adhesive property with hard and soft tissue structures. So, it can be used for repair of organs, mucosa, skin, nerves, vessels and closure of wounds. ${ }^{6,7,8}$

Clinical use of N Butyl 2 cyanoacrylate was approved at the beginning of 1996. It is becoming a popular method for closure of wound under less tension. It provides good cosmetic closure than suturing. Moreover it has minimal time to apply and is a pain free method of closure than the suturing. It has advantages of better tensile strength and readily polymerize even in contact with moisture. We can increase the flexibility of the material by adding the plasticizer to the $\mathrm{N}$ Butyl 2 cyanoacrylate. It can also be used for the management of arteriovenous malformations, gastric and oesophageal varices and for embolizations. Nowadays it is most commonly used for management of intracranial arteriovenous malformations. ${ }^{10}$

Absorbable suture material is commonly used in various surgical procedures like general surgery, gynecological surgery, ophthalmic surgery, neurosurgery and dermatology. Vicryl is an absorbable, safe and non toxic product. It is available in the form of coated as well as non coated form.

Vicryl is a synthetic, monofilament/multifilament absorbable suture material. It is a copolymer of lactide and glycolide coated with polygalactin 370 and calcium stearate. Tissue reaction of viryl suture is mild. Vicryl 910 or vicryl plus is coated with triclosan material. ${ }^{11}$ Triclosan is a broad spectrum antibacterial agent and effective against the most common pathogens associated with surgical site infections. In vicryl rapide, it is treated with gamma irradiation and become low molecular weight than coated vicryl. It loses all its strength between 10 to $12^{\text {th }}$ days and gets totally absorbed within 42 days.

To achieve proper wound healing, the incision should be accurate, tissue handling should be delicate, precise wound reapproximation, closure material should have ideal working property and aseptic. Various other factors also contributing for ideal wound healing are systemic health, nutritional status, immune responses of individual and presence or absence of infection in the wound.

The purpose of present study is clinically comparing the efficacy of $\mathrm{N}$ Butyl 2 Cyanoacrylate and vicryl suture in intra oral mucosal incision.

\section{Materials \& Methods}

\section{Study design}

This is a comparative interventional study for comparing the efficacy of $\mathrm{N}$ Butyl 2 cyanoacrylate and vicryl suture in intra oral wound closure.

\section{Study setting}

Patients who reported to the Department of Oral and Maxillofacial surgery, Sree Mookambika Institute of Dental science, Kulasekharam, K.K district, Tamilnadu were included in the study. Thirty patients who fulfilled the inclusion criteria formed the study sample.

\section{Number of group}

Two group.

\section{Description of group}

Thirty patients reporting for intra oral mucosal incision for extraction procedure were included in this study.

Group I: Incision closed with vicryl suture material.

Group II: Incision closed with N Butyl 2 cyanoacrylate material.

\section{Sample size of each group:}

30 patients

Total sample size of the study

60(30 patients)

\section{Scientific basis of sample size used in study}

Sample size is formula used here is

Where $\mathrm{p}=\frac{\mathrm{p}_{1}+\mathrm{p}_{2}}{2}$

$\mathrm{Q}=1-\mathrm{p}$

$\mathrm{P}_{1}=$ proportion of 1 group

$\mathrm{P}_{2}=$ proportion of 2 group

$\mathrm{Z} \alpha=1.96$

$\mathrm{Z} \beta=0.84$

\section{Sampling Technique}

Convenient sampling technique

\section{Selection Criteria}

\section{Inclusion Criteria}

- Patient in the age group of $18-55$ years will be selected irrespective of sex, caste, religion and socio-economic status. 


\section{International Journal of Science and Research (IJSR) \\ ISSN (Online): 2319-7064}

Index Copernicus Value (2015): 78.96 | Impact Factor (2015): 6.391

- Bilaterally symmetrical mucoperiosteal flap with the same length and design for removal of teeth and alveoloplasty procedures were included.

- Only clean incisions which can be approximated without tension using cyanoacrylate were included.

- Length of incision should be 1 to 3 centimeter.

- Patients who agreed to follow the study protocol.

Exclusion criteria:

- Immunodeficiency disease.

- Uncontrolled systemic diseases.

- Patient with anti-coagulant therapy.

- Smoker.

- Uncooperative patients; mentally retarded patients.

- Patients, who are likely not to maintain their oral hygiene.

- Flap, which cannot be approximated passively.

- Patients not willing to commit to an appropriate post procedure follow-up.

This study protocol was reviewed then approved by our departmental review board, research committee, ethical committee and all the patients in this study were informed of the benefits and possible risks of this procedure.

\section{Parameters to be studied}

Pain-observed based on visual analogue scale.

Wound dehiscence/gaping- observed clinically by visual examination only.

\section{Armamentarium}

- Mouth mirror(sirag surgical)

- Straight probes(sirag surgical)

- Tweezers(sirag surgical)

- Towel clips(sirag surgical)

- Suction cannula(sirag surgical)

- Disposable syringe $(2 \mathrm{ml})$ with needles $(24$ gauge)(Dispovan).

- Lignox 2\%.(Lignocaine2\% with adrenaline 1:80,000Warren indoco)

- Surgical scalpel No:3(sirag surgical)

- Bard Parker blade no. 15(from Paramount surgimed Ltd)

- Periosteal elevators No -9(sirag surgical)

- Straight elevators(sirag surgical)

- Winters Cryer's elevator(sirag surgical)

- Bone file(sirag surgical)

- Bone rongeur(sirag surgical)

- Needle holder(sirag surgical)

- Adsons tissue forceps(sirag surgical)

- Scissors(sirag surgical)

- Straight mosquito forceps(sirag surgical)

- 3-0 vicryl(Ethicon)

- Pre-sterilized N-Butyl 2- cyanoacrylate ampule(Reevax life sciences)

\section{Procedure in detail}

After proper case recording and selecting the patients, the surgical procedure and also the use of n-butyl cyanoacrylate tissue adhesive for closure of surgical wounds as an alternative to sutures was explained thoroughly to the patients. Under aseptic precautions, patient was anaesthetized with $2 \%$ lignocaine with adrenaline 1:80000(LIGNOX-2\% manufactured by Warren indoco) and prepared for surgery. The length of incision varied from 1-3 $\mathrm{cm}$ depending on the surgical access required for the procedure. The extraction procedure performed, if required alveolopasty procedures will be performed. After performing the surgical procedure and achieving adequate hemostasis, closures was performed on one side with n-butyl cyanoacrylate tissue adhesive and on the other side with 3-0 vicryl and these sides were randomly chosen. The side of the incision where n-butyl cyanoacrylate tissue adhesive was to be applied, isolated with dry gauze. The incised edges were accurately approximated, trying not to leave any gap between them. $\mathrm{N}$ butyl 2-cyanoacrylate was applied at the approximated wound margins in the form of drops for closure of the mucoperiosteal flaps. Same surgical procedure performed on other side also, incision was closed with 3-0 Vicryl suture. The post-operative sites pressure pack was given at the sutured sites. Post-operative instructions regarding diet, avoid disrupting the wound at glue site, oral hygiene maintenance and warm saline gargles were given to the patients.

Following medications with their standard dosages were given:-

1) Tab. Fenacplus(Diclofenac sodium $50 \mathrm{mg}+$ Paracetamol $500 \mathrm{mg}$ ) twice a day for three days

2) Cap. Amox 500mg(Amoxycillin) thrice a day for five days

Follow-up was made at third, fifth and seventh postoperative days. During each follow up visit, pain was recorded on a visual analogue scale. The pain scale was 4 $\mathrm{cm}$ long subdivided into 4 equal parts, one end corresponding to no pain, the other to extremely severe pain. It will be recorded at $1^{\text {st }}$ day, $3^{\text {rd }}$ day, $5^{\text {th }}$, and $7^{\text {th }}$ day.

Visual analog scale to evaluate pain: reference values were given to patients

\begin{tabular}{|c|c|c|}
\hline 0 & No pain & patient feels well \\
\hline 1 & Mild pain & $\begin{array}{l}\text { patient is distracted he or she does not feel } \\
\text { the pain }\end{array}$ \\
\hline 2 & Severe pain & $\begin{array}{l}\text { patient is very disturbed but nevertheless } \\
\text { can continue with normal activities }\end{array}$ \\
\hline 3 & $\begin{array}{l}\text { Very severe } \\
\text { pain }\end{array}$ & $\begin{array}{c}\text { patient is forced to abandon normal } \\
\text { activities }\end{array}$ \\
\hline
\end{tabular}

Wound dehiscence was observed clinically on $1^{\text {st }}$ day, $3^{\text {rd }}$ day, $5^{\text {th }}$ and $7^{\text {th }}$ post operative days based on visual examination.

Statistical analysis of the information obtained was performed. The differences with a $\mathrm{P}<0.05$ were found to be statistically significant. 
International Journal of Science and Research (IJSR)

ISSN (Online): 2319-7064

Index Copernicus Value (2015): 78.96 | Impact Factor (2015): 6.391

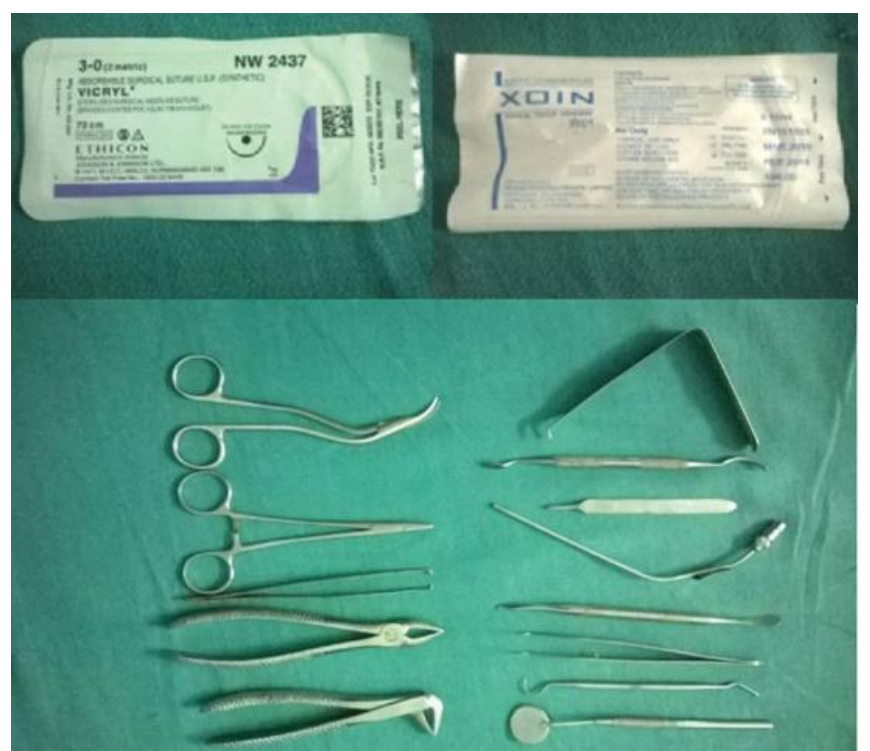

Armamentarium

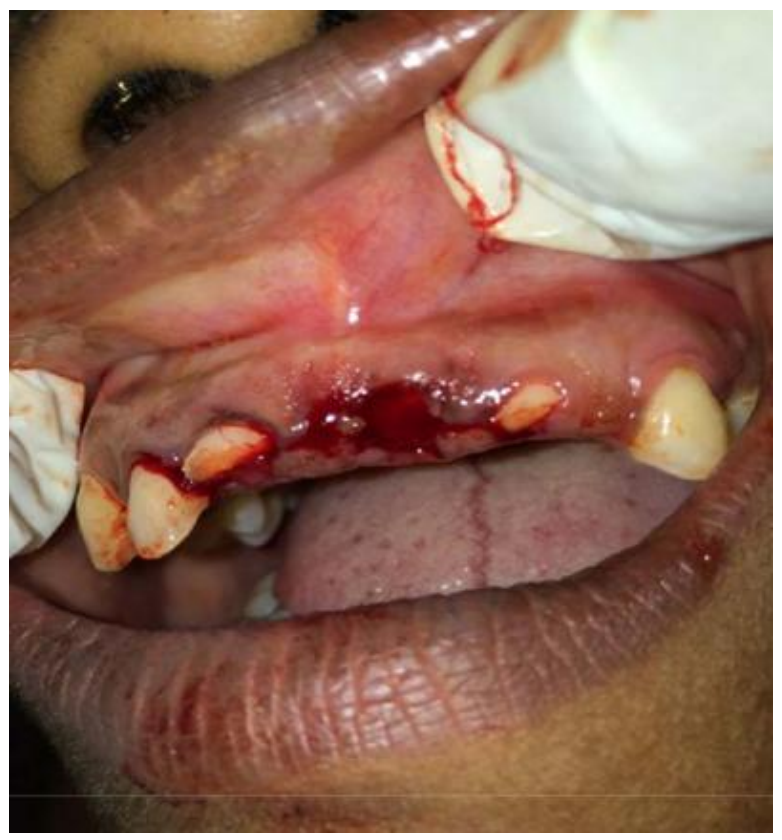

Immediate Post Extraction of 21

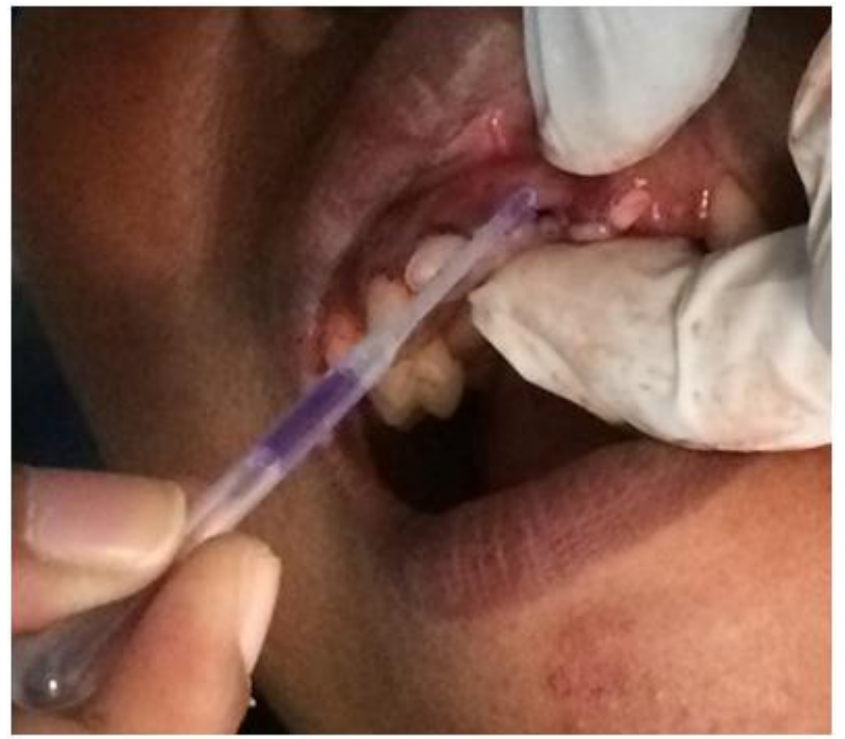

Application of N Butyl 2 Cyanoacrylate

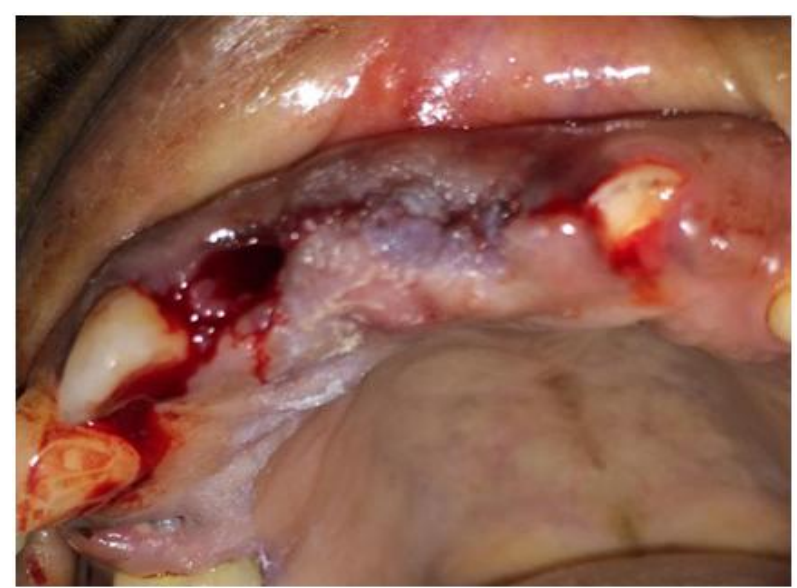

Immediate Post Extraction of 11

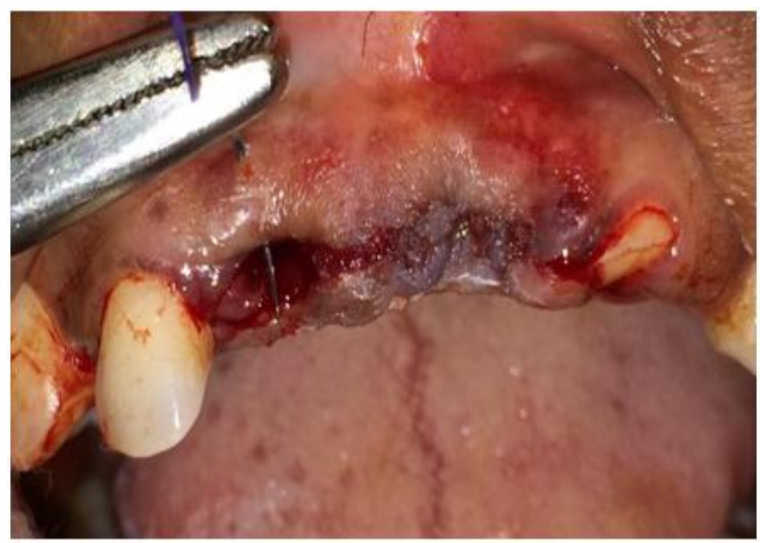

Suturing Wound With Vicryl

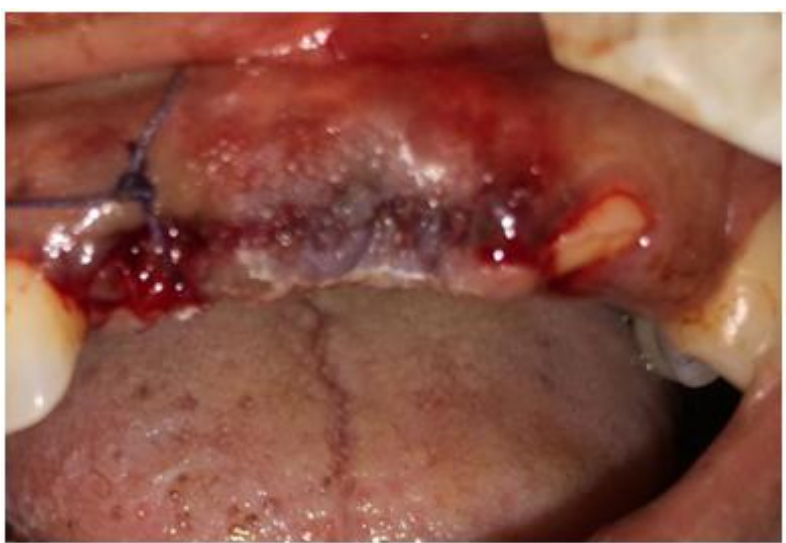

On Day -1

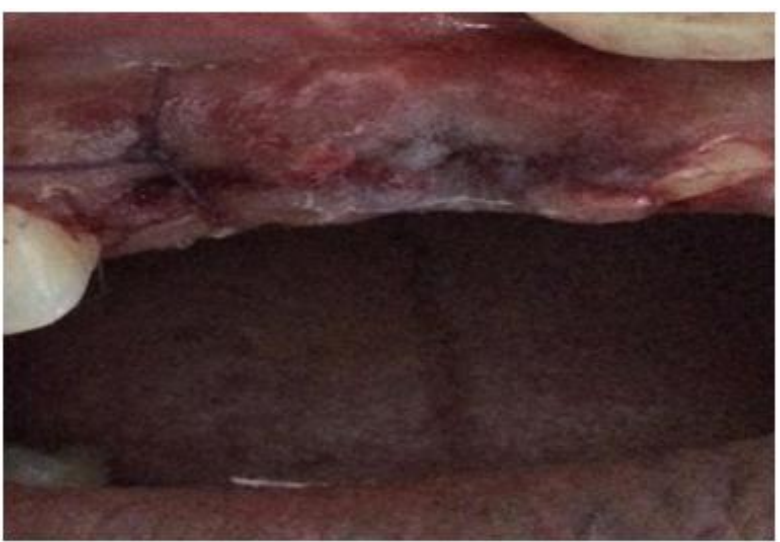

On Day -3

Volume 6 Issue 1, January 2017

www.ijsr.net 


\section{International Journal of Science and Research (IJSR) ISSN (Online): 2319-7064}

Index Copernicus Value (2015): 78.96 | Impact Factor (2015): 6.391

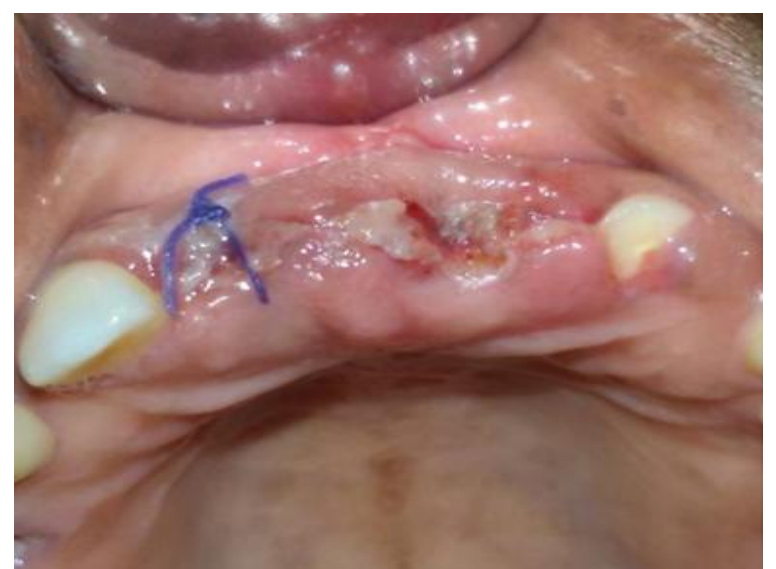

On Day -5

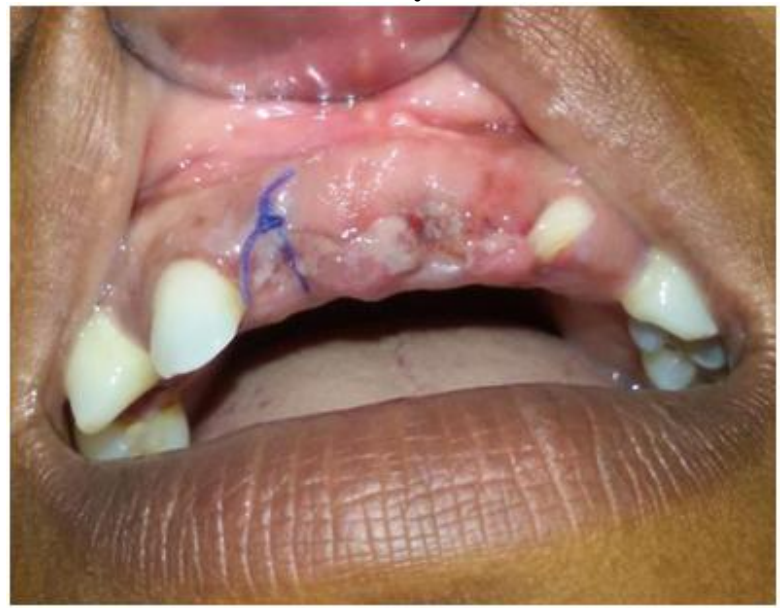

On Day -7

\section{Result}

\section{Statistical analysis:}

The study wa s analyzed by Statistical Analysis for Social Science s (SPSS 16.0) version. Chi square test a pplied to $f$ ind the si gnificant $b$ etween the groups. $P$ value less than $0.05(\mathrm{p}<0.05)$ considered s tatistically significant at $95 \%$ co nfidence interval.

Table 1: Demographic data

\begin{tabular}{|c|c|c|c|c|c|}
\hline \multirow{2}{*}{$\begin{array}{c}\text { Demo- } \\
\text { graphic } \\
\text { data }\end{array}$} & \multirow{2}{*}{$\begin{array}{c}\text { Age } \\
\text { MEAN } \pm\end{array}$} & \multicolumn{4}{|c|}{ Gender } \\
\cline { 3 - 6 } & SD) & Number & $\begin{array}{c}\text { Percentage } \\
(\%)\end{array}$ & Number & $\begin{array}{c}\text { Percentage } \\
(\%)\end{array}$ \\
\hline Groups & $38.47 \pm 4.56$ & 15 & 50.00 & 15 & 50.00 \\
\hline
\end{tabular}

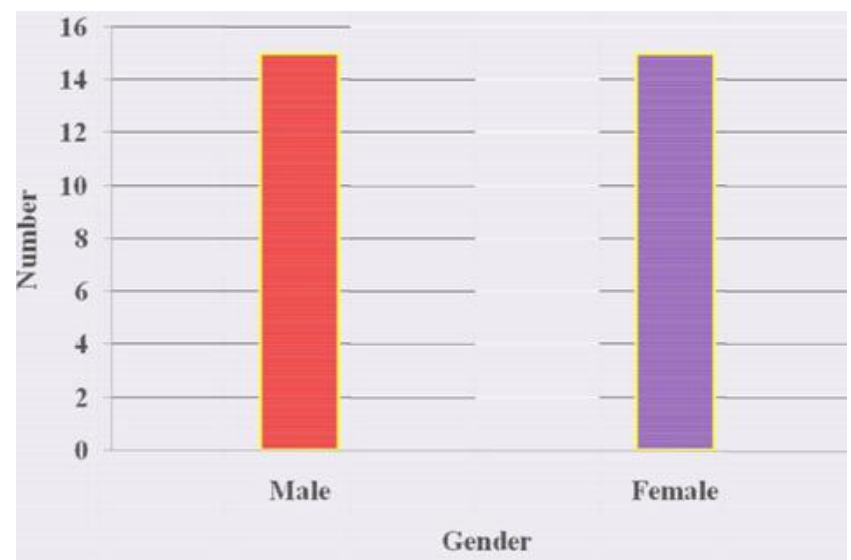

Graph 1: Distribution of patients according to gender

\section{Result}

Table 2: Number and percentage of patients based on presence of wound dehiscence at different time periods

\begin{tabular}{|c|c|c|c|c|c|c|c|c|}
\hline \multirow{2}{*}{ Groups } & \multicolumn{2}{|c|}{ Day 1 } & \multicolumn{2}{c|}{ Day 3 } & \multicolumn{2}{c|}{ Day 5 } & \multicolumn{2}{c|}{ Day 7 } \\
\cline { 2 - 9 } & Number & $\%$ & Number & $\%$ & Number & $\%$ & Number & $\%$ \\
\hline Group-I & 2 & 6.7 & 9 & 30 & 16 & 53.3 & 18 & 60 \\
\hline Group-II & 6 & 20 & 14 & 46.7 & 17 & 56.7 & 19 & 63.3 \\
\hline
\end{tabular}

Table 3: Number and percentage of patients based on absence of wound dehiscence at different time periods

\begin{tabular}{|c|c|c|c|c|c|c|c|c|}
\hline \multirow{2}{*}{\begin{tabular}{c} 
Groups \\
\cline { 2 - 9 }
\end{tabular}} & \multicolumn{2}{|c|}{ Day 1 } & \multicolumn{2}{c|}{ Day 3 } & \multicolumn{2}{c|}{ Day 5 } & \multicolumn{2}{c|}{ Day 7 } \\
\hline $\begin{array}{c}\text { Group- } \\
\text { I }\end{array}$ & 28 & 93.33 & 21 & 70.00 & 4 & 46.67 & 12 & 40.00 \\
\hline $\begin{array}{c}\text { Group- } \\
\text { II }\end{array}$ & 24 & 80.00 & 16 & 53.33 & 13 & 43.33 & 11 & 36.67 \\
\hline
\end{tabular}

Table 4: Comparison of wound dehiscence between the groups at day 1

\begin{tabular}{|c|c|c|c|c|c|}
\hline \multirow{3}{*}{ Groups } & \multicolumn{4}{|c|}{ Day 1} & \multirow{3}{*}{$\begin{array}{c}\mathrm{p} \\
\text { value }\end{array}$} \\
\hline & \multicolumn{2}{|c|}{ Presence } & \multicolumn{2}{|c|}{ Absence } & \\
\hline & Number & $\begin{array}{c}\text { Percentage } \\
(\%)\end{array}$ & Number & $\begin{array}{c}\text { Percentage } \\
(\%)\end{array}$ & \\
\hline Group-I & 2 & 6.67 & $28^{\#}$ & 93.33 & \multirow{3}{*}{0.03} \\
\hline Group-II & 6* & 20 & $24^{\#}$ & 80 & \\
\hline $\mathrm{p}$ value & & 0.04 & & 0.87 & \\
\hline
\end{tabular}

Table 5: Comparison of wound dehiscence between the groups at day 3

\begin{tabular}{|c|c|c|c|c|c|}
\hline \multirow{3}{*}{ Groups } & \multicolumn{4}{|c|}{ Day 3} & \multirow{3}{*}{$\mathrm{p}$ value } \\
\hline & \multicolumn{2}{|c|}{ Presence } & \multicolumn{2}{|c|}{ Absence } & \\
\hline & Number & $\begin{array}{c}\text { Percentage } \\
(\%)\end{array}$ & Number & $\begin{array}{c}\text { Percentage } \\
(\%)\end{array}$ & \\
\hline \begin{tabular}{|l|} 
Group-I \\
\end{tabular} & 9 & 30 & $21^{\#}$ & 70 & \multirow{3}{*}{0.03} \\
\hline Group-II & $14 *$ & 46.67 & $16^{*}$ & 53.33 & \\
\hline $\mathrm{p}$ value & \multicolumn{2}{|r|}{0.02} & \multicolumn{2}{|c|}{0.45} & \\
\hline
\end{tabular}

Table 6: Comparison of wound dehiscence between the groups at day 5

\begin{tabular}{|c|c|c|c|c|c|}
\hline \multirow{3}{*}{ Groups } & \multicolumn{4}{|c|}{ Day 5} & \multirow{3}{*}{$\begin{array}{c}\mathrm{p} \\
\text { value }\end{array}$} \\
\hline & \multicolumn{2}{|c|}{ Presence } & \multicolumn{2}{|c|}{ Absence } & \\
\hline & Number & $\begin{array}{c}\text { Percentage } \\
(\%)\end{array}$ & Number & $\begin{array}{c}\text { Percentage } \\
(\%)\end{array}$ & \\
\hline Group-I & 16 & 53.33 & $14^{\#}$ & 46.67 & \multirow{3}{*}{0.04} \\
\hline Group-II & 17 & 56.67 & $13^{\#}$ & 43.33 & \\
\hline $\mathrm{p}$ value & \multicolumn{2}{|c|}{0.78} & \multicolumn{2}{|c|}{0.67} & \\
\hline
\end{tabular}

$(\mathrm{p}>0.05$ no significant compared between the groups, ${ }^{\#} \mathrm{p}<0.05$ significant compared within the groups)

Table 7: Comparison of wound dehiscence between the groups at day 7

\begin{tabular}{|c|c|c|c|c|c|}
\hline \multirow{3}{*}{ Groups } & \multicolumn{4}{|c|}{ Day 7} & \multirow{3}{*}{$\mathrm{p}$ value } \\
\hline & \multicolumn{2}{|c|}{ Presence } & \multicolumn{2}{|l|}{ Absence } & \\
\hline & Number & $\begin{array}{c}\text { Percentage } \\
(\%)\end{array}$ & Number & $\begin{array}{c}\text { Percentage } \\
(\%)\end{array}$ & \\
\hline Group-I & 18 & 60 & $12^{\#}$ & 40 & \multirow{3}{*}{0.02} \\
\hline Group-II & 19 & 63.33 & $11^{\#}$ & 36.67 & \\
\hline $\mathrm{p}$ value & \multicolumn{2}{|r|}{0.45} & \multicolumn{2}{|c|}{0.19} & \\
\hline
\end{tabular}

\section{Volume 6 Issue 1, January 2017




\section{International Journal of Science and Research (IJSR) \\ ISSN (Online): 2319-7064}

Index Copernicus Value (2015): 78.96 | Impact Factor (2015): 6.391

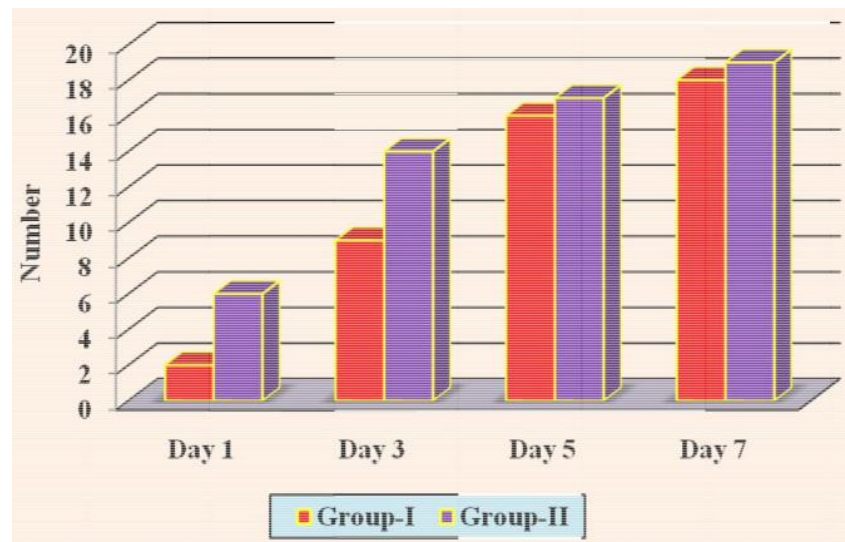

Graph 2: N umber and percentage of patient s based on presence of wound dehiscence at different time perio ds

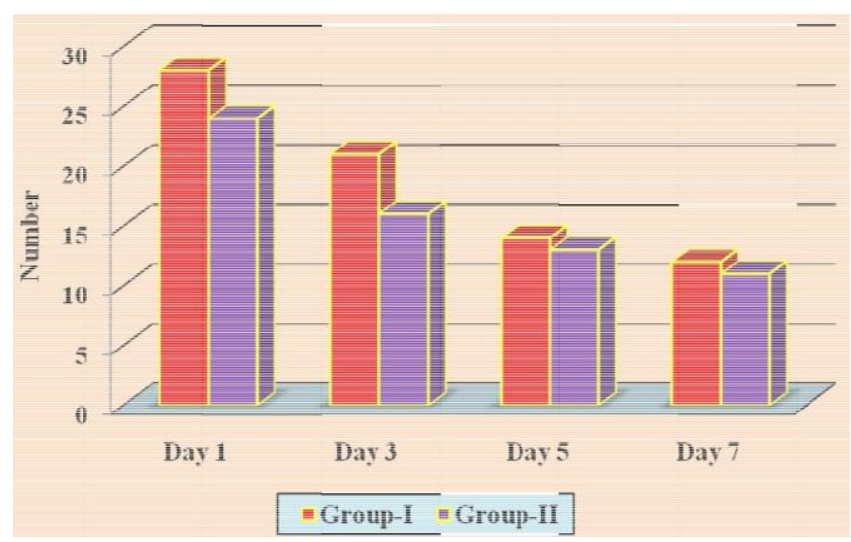

Graph 3: $N$ umber and percentage of patients based on absence of wound dehiscence at different time perio ds

Table 8: Comparison of number and percentage of patients based on the pain score on day 1

\begin{tabular}{|c|c|c|c|c|}
\hline \multirow{2}{*}{$\begin{array}{c}\text { Pain } \\
\text { Score }\end{array}$} & \multicolumn{2}{|c|}{ Group-I } & \multicolumn{2}{c|}{ Group-II } \\
\cline { 2 - 5 } & Number & Percentage (\%) & Number & Percentage (\%) \\
\hline Score 0 & 0 & 0 & 1 & 3.33 \\
\hline Score 1 & $9^{*}$ & 30 & $11^{*}$ & 36.67 \\
\hline Score 2 & $18^{*, \#}$ & 60 & $17^{*, \#}$ & 56.67 \\
\hline Score 3 & $3^{*, \#, \$}$ & 10 & $1^{\#, \$}$ & 3.33 \\
\hline
\end{tabular}

$\left({ }^{*} \mathrm{p}<0.05\right.$ significant compared score 0 with other scores within the groups,

${ }^{\#} \mathrm{p}<0.05$ significant compared score 1 with other scores within the groups, ${ }^{\$} \mathrm{p}<0.05$ significant compared score 2 with other scores within the groups)

Table 9: Comparison of number and percentage of patients based on the pain score on day 3

\begin{tabular}{|c|c|c|c|c|}
\hline $\begin{array}{c}\text { Pain } \\
\text { Score }\end{array}$ & \multicolumn{2}{|c|}{ Group-I } & \multicolumn{2}{c|}{ Group-II } \\
\cline { 2 - 5 } & Number & $\begin{array}{c}\text { Percentage } \\
(\%)\end{array}$ & Number & $\begin{array}{c}\text { Percentage } \\
(\%)\end{array}$ \\
\hline Score 0 & 7 & 23.33 & 10 & 33.33 \\
\hline Score 1 & $15^{*}$ & 50 & $15^{*}$ & 50 \\
\hline Score 2 & $8^{\#}$ & 26.67 & $5^{*, \#}$ & 16.67 \\
\hline Score 3 & $0^{*}, \#, \$$ & 0 & $0^{*, \#, \$}$ & 0 \\
\hline
\end{tabular}

$\left({ }^{*} p<0.05\right.$ significant compared score 0 with other scores within the groups,
${ }^{\#} \mathrm{p}<0.05$ significant compared score 1 with other scores within the groups, ${ }^{\$}<0.05$ significant compared score 2 with other scores within the group

Table 10: Comparison of number and percentage of patients based on the pain score on day 5

( $* \mathbf{p}<0.05$ significant compared score 0 with other scores within the groups,

${ }^{\#} \mathbf{p}<0.05$ significant compared score 1 with other scores within the groups, ${ }^{\$} \mathbf{p}<0.05$ significant compared score 2 with other scores within the groups)

Table 11: Comparison of number and percentage of patients based on the pain score on day 7

\begin{tabular}{|c|c|c|c|c|}
\hline \multirow{2}{*}{$\begin{array}{c}\text { Pain } \\
\text { Score }\end{array}$} & \multicolumn{2}{|c|}{ Group-I } & \multicolumn{2}{c|}{ Group-II } \\
\cline { 2 - 5 } & Number & Percentage (\%) & Number & Percentage (\%) \\
\hline Score 0 & 19 & 63.33 & 20 & 66.67 \\
\hline Score 1 & $11^{*}$ & 36.67 & $10^{*}$ & 33.33 \\
\hline Score 2 & $0^{*, \#}$ & 0 & $0^{*, \#}$ & 0 \\
\hline Score 3 & $0^{*}, \#$ & 0 & $0^{*}, \#$ & 0 \\
\hline
\end{tabular}

$(* \mathrm{p}<0.05$ significant compared score 0 with other scores within the groups,

${ }^{\#} \mathrm{p}<0.05$ significant compared score 1 with other scores within the groups, ${ }^{\$} \mathrm{p}<0.05$ significant compared score 2 with other scores within the groups)

Table 12: Comparison of number of patients based on the pain score between the groups at different pain scores on day 1

\begin{tabular}{|c|c|c|c|c|}
\hline Groups & Score 0 & Score 1 & Score 2 & Score 3 \\
\hline Group-I & 0 & 9 & 18 & 3 \\
\hline Group-II & 1 & $11^{*}$ & 17 & 1 \\
\hline $\mathrm{p}$ value & 0.23 & 0.04 & 0.45 & 0.83 \\
\hline \multicolumn{2}{|c}{${ }^{*} \mathrm{p}<0.05$ significant compared score 1 between the groups $)$} \\
\hline
\end{tabular}

Table 13: Comparison of number of patients based on the pain score between the groups at different pain scores on day 3

\begin{tabular}{|c|c|c|c|c|}
\hline Groups & Score 0 & Score 1 & Score 2 & Score 3 \\
\hline Group-I & 7 & 15 & 8 & 0 \\
\hline Group-II & 10 & 15 & 5 & 0 \\
\hline $\mathrm{p}$ value & 0.45 & 0.67 & 0.29 & \\
\hline ( $>0.05$ no significant compared between the groups) \\
\hline
\end{tabular}

Table 14: Comparison of number of patients based on the pain score between the groups at different pain scores on day 5

\begin{tabular}{|c|c|c|c|c|}
\hline Groups & Score 0 & Score 1 & Score 2 & Score 3 \\
\hline Group-I & 19 & 11 & 0 & 0 \\
\hline Group-II & 20 & 10 & 0 & 0 \\
\hline $\mathrm{p}$ value & 0.67 & 0.19 & & \\
\hline & $(\mathrm{p}>0.05$ no significant compared between the groups) \\
\hline
\end{tabular}

Table 15: Comparison of number of patients based on the pain score between the groups at different pain scores on day 7

\begin{tabular}{|c|c|c|c|c|}
\hline Groups & Score 0 & Score 1 & Score 2 & Score 3 \\
\hline Group-I & 26 & 4 & 0 & 0 \\
\hline Group-II & 27 & 3 & 0 & 0 \\
\hline $\mathrm{p}$ value & 0.28 & 0.56 & & \\
\hline ( $>0.05$ no significant compared between the groups) \\
\hline
\end{tabular}


International Journal of Science and Research (IJSR)

ISSN (Online): 2319-7064

Index Copernicus Value (2015): 78.96 | Impact Factor (2015): 6.391

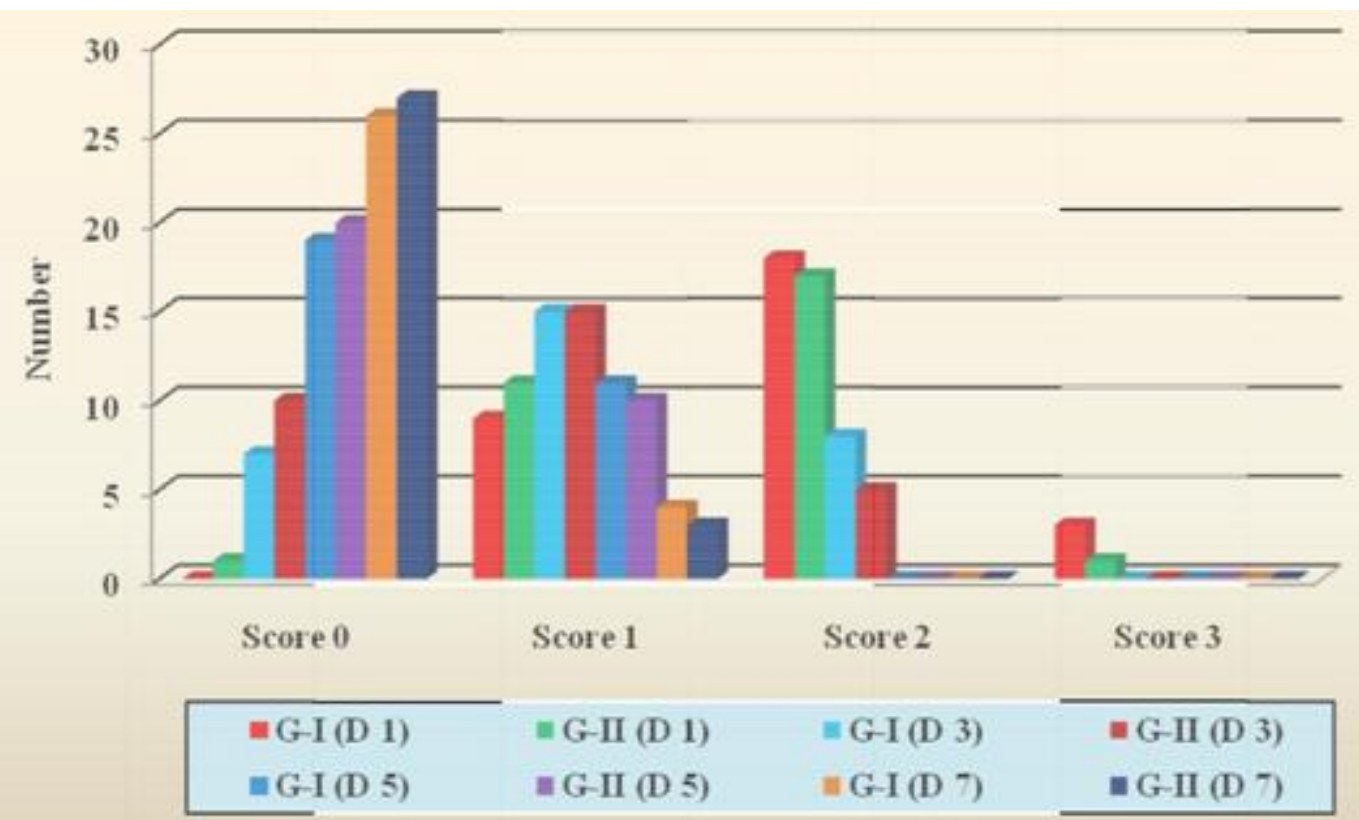

Graph 4: Comparison of pain score between the groups

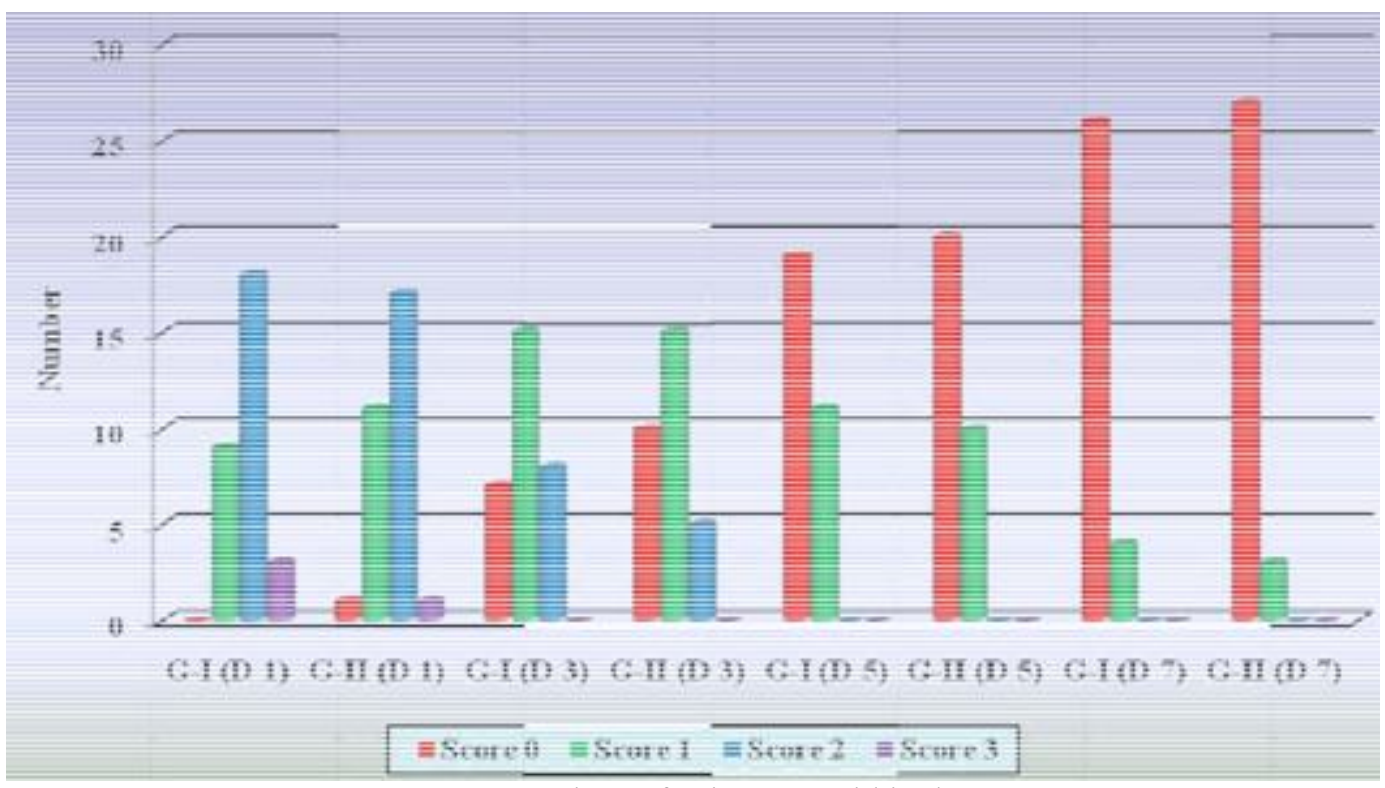

Graph 5: Comparison of pain score within the groups

Group I- In cision clos ed with vic ryl suture..

Group II- Incision clo sed with N Butyl 2 cyanoacrylate

\section{Interpretation}

Table 1: Comparison of gender involving this study and the mean age of the patient.

Table 2: Comparison of presence of wound dehiscence at different time periods. In group I, $6.67 \%$ of wound dehiscence was observed on first day, $30 \%$ of wound dehiscence was observed $3^{\text {rd }}$ day, $53.33 \%$ of wound dehiscence was observed on $5^{\text {th }}$ day, $60 \%$ of wound dehiscence was observed on $7^{\text {th }}$ day. In group II, $20 \%$ of wound dehiscence was observed on $1^{\text {st }}$ day, $46.67 \%$ of wound dehiscence was observed on $3^{\text {rd }}$ day, $56.67 \%$ of wound dehiscence was observed on $5^{\text {th }}$ day, $63.33 \%$ of wound dehiscence was observed on $7^{\text {th }}$ day.
Table 3: Comparison of absence of wound dehiscence at different time periods. In group I, wound dehiscence was not observed in $93.33 \%$ on $1^{\text {st }}$ day, wound dehiscence was not observed in $70 \%$ on $3^{\text {rd }}$ day, wound dehiscence was not observed in $46.67 \%$ on $5^{\text {th }}$ day, wound dehiscence was not observed in $40 \%$ on $7^{\text {th }}$ day. In group II, wound dehiscence was not observed in $80 \%$ on $1^{\text {st }}$ day, wound dehiscence was not observed in $53.33 \%$ on $3^{\text {rd }}$ day, wound dehiscence was not observed in $43.33 \%$ on $5^{\text {th }}$ day, wound dehiscence was not observed in $36.67 \%$ on $7^{\text {th }}$ day.

Table 4: Comparison of wound dehiscence between group I and group II on day 1. In group I wound dehiscence was observed in $6.67 \%$ on $1^{\text {st }}$ day, in group II wound dehiscence was observed $20 \%$ on $1^{\text {st }}$ day. In group I, wound dehiscence was not observed in $93.3 \%$ on $1^{\text {st }}$ day, in group II wound dehiscence was not observed in $80 \%$ on $1^{\text {st }}$ day. There was statistically significant difference between group I and group II in comparing presence of wound dehiscence. 


\section{International Journal of Science and Research (IJSR) \\ ISSN (Online): 2319-7064}

Index Copernicus Value (2015): 78.96 | Impact Factor (2015): 6.391

Table 5: Comparison of wound dehiscence between group I and group II on day 3. In group I wound dehiscence was observed in $30 \%$ on $3^{\text {rd }}$ day, in group II wound dehiscence was observed $46.67 \%$ on $3^{\text {rd }}$ day. In group I, wound dehiscence was not observed in $70 \%$ on $3^{\text {rd }}$ day, in group II wound dehiscence was not observed in $53.33 \%$ on $3^{\text {rd }}$ day. There was statistically significant difference between group I and group II in comparing presence of wound dehiscence.

Table 6: Comparison of wound dehiscence between group I and group II on day 5. In group I wound dehiscence was observed in $53.33 \%$ on $5^{\text {th }}$ day, in group II wound dehiscence was observed $56.67 \%$ on $5^{\text {th }}$ day. In group I, wound dehiscence was not observed in $46.67 \%$ on $5^{\text {th }}$ day, in group II wound dehiscence was not observed in $43.33 \%$ on $5^{\text {th }}$ day. There was statistically no significant difference between group I and group II

Table 7: Comparison of wound dehiscence between group I and group II on day 7 . In group I wound dehiscence was observed in $60 \%$ on $7^{\text {th }}$ day, in group II wound dehiscence was observed $63.33 \%$ on $7^{\text {th }}$ day. In group I, wound dehiscence was not observed in $40 \%$ on $7^{\text {th }}$ day, in group II wound dehiscence was not observed in $36.67 \%$ on $7^{\text {th }}$ day. There was statistically no significant difference between group I and group II.

Table 8: Comparison of number and percentage of patients based on the pain score on $1^{\text {st }}$ day. Group I, all patient experienced pain, $30 \%$ experienced mild pain (score 1), $60 \%$ experienced severe pain (score 2 ), 10\% experienced very severe pain. Group II, 3.33\% patient not experienced pain (score 0 ), 36.67\% experienced mild pain (score 1), 56.67\% experienced severe pain(score2), 3.33\% experienced very severe pain. There was statistically no significant difference between group I and group II.

Table 9: Comparison of number and percentage of patients based on the pain score on $3^{\text {rd }}$ day. Group I, $23.33 \%$ experienced no pain(score 0 ), $50 \%$ experienced

mild pain(score 1), 26.67\% experienced severe pain(score2), $0 \%$ experienced very severe pain(score 3).Group II, 33.33\% patient not experienced pain(score 0 ), $50 \%$ experienced mild pain(score 1), $16.67 \%$ experienced severe pain(score 2 ), $0 \%$ experienced very severe pain(score 3). There was statistically no significant difference between group I and group II.

Table 10: Comparison of number and percentage of patients based on the pain score on $5^{\text {th }}$ day. Group I, $63.33 \%$ experienced no pain(score0), 36.67\% experienced mild pain(score 1), $0 \%$ experienced severe pain(score 2 ), $0 \%$ experienced very severe pain(score 3).Group II, $66.67 \%$ patient not experienced pain(score 0$), 33.33 \%$ experienced mild pain(score 1), $0 \%$ experienced severe pain(score 2 ), $0 \%$ experienced very severe pain(score 3). There was statistically no significant difference between group I and group II.

Table 11: Comparison of number and percentage of patients based on the pain score on $7^{\text {th }}$ day. Group I, $86.67 \%$ experienced no pain(score 0$), 13.33 \%$ experienced mild pain(score 1), $0 \%$ experienced severe pain(score 2 ), $0 \%$ experienced very severe pain(score 3).Group II, 90\% patient not experienced pain(score 0$), 10 \%$ experienced mild pain(score 1), $0 \%$ experienced severe pain(score 2 ), $0 \%$ experienced very severe pain(score 3). There was statistically no significant difference between group I and group II.

Table 12: Comparison between groups based on the pain score on $1^{\text {st }}$ day. Group I- all experienced pain (score 0$), 9$ experienced mild pain (score 1), 18 experienced severe pain (score 2), 3 experienced very severe pain (score 3 ). Group II1 experienced no pain (score 0), 11 experienced mild pain (score 1), 17 experienced severe pain (score 2), 1 experienced very severe pain (score 3 ). $p<0.05$ There was statistically significant difference between group I and Group II on score 1.

Table 13: Comparison between the groups based on the pain score on $3^{\text {rd }}$ day. Group I- 7 experienced no pain (score 0 ), 15 experienced mild pain (score 1), 8 experienced severe pain (score 2), 0 experienced very severe pain (score 3 ). Group II-10 experienced no pain (score 0), 15 experienced mild pain (score 1), 5 experienced severe pain (score 2), 0 experienced very severe pain (score 3 ). $\mathrm{p}>0$. There was statistically no significant difference between group I and group II.

Table 14: Comparison between the groups based on the pain score on $5^{\text {th }}$ day. Group I- 19 experienced no pain (score 0 ), 11 experienced mild pain (score 1), 0 experienced severe pain (score 2), 0 experienced very severe pain (score 3 ). Group II-20 experienced no pain (score 0), 10 experienced mild pain (score 1), 0 experienced severe pain (score 2), 0 experienced very severe pain (score 3 ). p $>0.05$ There was statistically no significant difference between group I and group II.

Table 15: Comparison of both groups based on the pain score on $7^{\text {th }}$ day. Group I- 26 experienced no pain (score 0 ), 4 experienced mild pain (score 1), 0 experienced severe pain (score 2), 0 experienced very severe pain (score 3). Group II-27 experienced no pain (score 0 ), 3 experienced mild pain (score 1), 0 experienced severe pain (score 2), 0 experienced very severe pain (score 3 ). $\mathrm{p}>0.05$ There was statistically no significant difference between group I and group II.

Graph 1: In comparison of distribution of patient according to gender, both male and female were in equal proportion.

Graph 2: comparison of presence of wound dehiscence at different time periods. On day 1 , wound dehiscence was present in 2 patients in group I, 6 patients in group II. On day 3 , wound dehiscence was present in 9 patients in group I, 14 patients in group II. On day 5, wound dehiscence was present in 16 patients in group I, 17 patients in group II. On day 7 , wound dehiscence was present in 18 patients in group I, 19 patients in group II.

Graph 3: comparison of absence of wound dehiscence at different time periods. On day 1, wound dehiscence was absent in 28 patient in group I, 24 patient in group II. On day 3 , wound dehiscence was absent in 21 patient in group I, 16

\section{Volume 6 Issue 1, January 2017




\section{International Journal of Science and Research (IJSR) \\ ISSN (Online): 2319-7064}

Index Copernicus Value (2015): 78.96 | Impact Factor (2015): 6.391

patient in group II. On day 5, wound dehiscence was absent in 14 patient in group I, 13 patient in group II. On day 7, wound dehiscence was absent in 12 patient in group I, 11 patient in group II.

Graph 4: comparison of pain score between group I and group II at different time periods. There was statistically no significant difference between two groups.

Graph 5: Comparison of pain score within the group. Statistically significant difference present within the group at different time period for both groups.

\section{Discussion}

Wound healing is a reparative process of tissue after injury. Wound healing process is divided into four phases. Haemostasis is the first phase, Inflammation is the second phase, proliferation is the third face and maturation is the fourth phase. Immediately after injury, platelets adhered to the injured site. Then adhered platelets change its shape and release chemical mediators for clotting. Finally activates fibrin to form a clot. In inflammatory phase, inflammatory cells are released into wound and engulf the pathogen and dead cells. In proliferation phase growth of newly formed cells will occur. Angiogenesis, new collagen formation, epithelial tissue formation, granulation tissue formation and wound contraction will occur. During maturation period type III collagen is replaced by type I collagen. Wound healing is affected by local and systemic factors.

Wound closure can be done by primary intention, secondary intention and tertiary intention. In primary intention wound edges are re-approximated with sutures, staples and tissue adhesive like $\mathrm{N}$ Butyl 2 cyanoacrylate. Advantage of primary intention is to minimize scarring, faster healing when compared to secondary intention. Usually done in well repaired laceration, properly reduced bone fractures and healing after flap surgery. In secondary intention wound is allowed to granulate. Usually healing is slow and more scar tissue. In tertiary intention, wound is cleaned and debrided for 4 to 5 days before wound closure.

Attainment of ideal wound closure is the important factor for healing at surgical site. The wound closure material should re-approximate the wound edges properly for sufficient period for healing to occur. Ideal property of wound closure material is easy to apply, rapid application, biocompatibility, better tissue tolerance, enough tensile strength to retain the re-approximated wound edges, free from toxic substances and free from allergic reaction.

Usually intra oral incision is closed with suture material like vicryl and silk suture materials. Suture material is commonly used for wound closure than staples and tissue adhesives. Because of the property like better tensile strength, low dehiscence rate, proper wound closure. But it has disadvantage like crosshatched marks, needle penetration of normal tissue on either side of the wound, tissue reactivity, anxiety, and it is a time consuming procedure. Because of theses disadvantages alternative procedure become developed like tissue adhesive.
In 1949 Ardis discovered cyanoacrylates. In 1959 cover et al suggested its adhesive property. Initially it was rejected because of not biocompatibility to the tissue and more inflammatory reaction. Later in 1964 Tennese Eastman lab developed longer molecular cyanoacrylate, which one better biocompatibility and produces less inflammatory reaction.

Advantage of N Butyl 2 cyanoacryate over suture material is easy to handle, shorter duration of application, comfortable for anxiety and fear of patient, better bacteriostatic property, eliminate the risk of needle prick injury, decreased healing time, haemostatic property and better esthetic property.

In this comparative interventional study, $\mathrm{N}$ Butyl 2 cyanoacrylate and vicryl suture were compared in intraoral wound closure. Parameters for evaluation in this study was pain and wound dehiscence.

\section{Pain:}

Patient experienced more pain on day1, progressively pain get reduced on day 3, day 5 and day 7 for both groups. On day 1 , only one patient experienced no pain in group II, 9 patient experienced mild pain in group I, 11 patient experienced mild pain in group II, 18 patient experienced severe pain in group I, 17 patient experienced severe pain in group II, 3 patient experienced very severe pain group I, 1 patient experienced very severe pain in group II. Experience of pain between both groups on day 1 , score 1 is statistically significant.

On day 3- 7 patient experienced no pain in group I, 10 patient experienced no pain in group II, 15 patient experienced mild pain in group I, 15 patient experienced mild pain in group II, 8 patient experienced severe pain in group I, 5 patient experienced severe pain in group II, 0 patient experienced very severe pain group I, 0 patient experienced very severe pain in group II.

On day 5- 19 patient experienced no pain in group I, 20 patient experienced no pain in group II, 11 patient experienced mild pain in group I, 10 patient experienced mild pain in group II, 0 patient experienced severe pain in group I, 0 patient experienced severe pain in group II, 0 patient experienced very severe pain group I, 0 patient experienced very severe pain in group II.

On day 7- 26 patient experienced no pain in group I, 27 patient experienced no pain in group II, 4 patient experienced mild pain in group I, 3 patient experienced mild pain in group II, 0 patient experienced severe pain in group I, 0 patient experienced severe pain in group II, 0 patient experienced very severe pain group I, 0 patient experienced very severe pain in group II.

Difference in experience of pain between both groups on day1, day3, day5 and day 7 was statistically not significant ( $p>0.05)$ except on experience of mild pain between both groups on day 1 was statistically significant different.

\section{Wound dehiscence}

On $1^{\text {st }}$ day and $3^{\text {rd }}$ day percentage of wound dehiscence was more in group II than group I. On $5^{\text {th }}$ day and $7^{\text {th }}$ day percentage of wound dehiscence was more or less equal in 


\section{International Journal of Science and Research (IJSR) \\ ISSN (Online): 2319-7064}

Index Copernicus Value (2015): 78.96 | Impact Factor (2015): 6.391

group I and group II. In day one, percentage of wound dehiscence in group I was 6.67 , for group II was 20 . In day 3 , percentage of wound dehiscence in group I was 30, for group II was 46.67. In day 5, percentage of wound dehiscence in group I was 53.33, for group II was 56.67. In day 7 , percentage of wound dehiscence in group I was 60 , for group II was 63.33.

Difference in percentage of wound dehiscence between both groups in day 1 was statistically significant $(\mathrm{p}<0.05)$. Percentage of wound dehiscence was increased on day 3 on both group. Difference in percentage of wound dehiscence between both groups on day 3 was statistically significant $(p<0.05)$. Percentage of wound dehiscence was increased on day 5 on both groups. Difference in percentage of wound dehiscence between both groups on day 5 was statistically not significant $(\mathrm{p}>0.05)$. Percentage of wound dehiscence was increased on day 5 on both group. Difference in percentage of wound dehiscence between both groups on day 7 was statistically not significant $(\mathrm{p}>0.05)$.

$\mathrm{N}$ butyl 2 cyanoacrylate has the advantage of bacteriostatic and haemostatic property. Time consumed for application of $\mathrm{N}$ Butyl 2 cyanoacrylate was very low when compared to vicryl suture. Patient satisfaction was high on N Butyl 2 cyanoacrylate than vicryl suture. Effects of $\mathrm{N}$ Butyl 2 cyanoacrylate and vicryl suture in intra oral wound closure have not been evaluated on previous studies in cross over basis. In previous studies N Butyl 2 cyanoacrylate compared mainly with silk suture in intra oral wound closure.

Ajit D. Joshi et al clinically compare the efficacy of cyanoacrylate (tissue glue) and conventional suture after surgical removal of impacted mandibular third molars. He conducted a study on thirty patients. Based on his study, efficacy of wound closure with cyanoacrylate and conventional suturing were similar in the severity of pain, but use of cyanoacrylate showed better haemostasis. The present study showed severity of pain in both group was statistically no significant at the end of fifth day.

Mohammad Elshall et al conducted study for closure of intra oral incision with tissue adhesive of N Butyl 2 cyanoacrylate and silk suture. He conducted a study on 20 patients. He concluded that difference in pain score between N Butyl 2 cyanoacrylate and silk suture was not statistically significant. But patient anxiety and psychological stress was reduced with $\mathrm{N}$ Butyl 2 cyanoacrylate. The present study also showed severity of pain in both group was statistically no significant at the end of third, fifth and seventh day.

\section{Summary \& Conclusion}

Wound closure can be done by suture materials, staples and tissue adhesives. Purpose of this study is, clinically compare the efficacy of $\mathrm{N}$ Butyl 2 cyanoacrylate with vicryl suture, an in vivo study.

Intra oral mucosal incision was performed in all the patients for the purpose of tooth extraction due to dental caries and periodontal problems in the same jaw bilaterally or one in upper jaw and another one in lower arch.
Group I was intra oral mucosal incision was closed with vicryl suture material, main criteria was flap should be reapproximated passively, before suture. Pain was recorded by visual analogue scale. Wound dehiscence was recorded by direct visual examination. Pain and wound dehiscence recorded on $1^{\text {st }}$ day, $3^{\text {rd }}$ day, $5^{\text {th }}$ day and $7^{\text {th }}$ day.

Group II was intra oral mucosal incision was closed with $\mathrm{N}$ Butyl 2 cyanoacrylate, before apply this material after the extraction, the flap was re-approximated passively. Parameters of pain and wound dehiscence was recorded on $1^{\text {st }}$ day, $3^{\text {rd }}$ day, $5^{\text {th }}$ day and $7^{\text {th }}$ day. Pain was recorded by visual analogue scale. Wound dehiscence was recorded by direct visual examination.

In this study, statistically significant more score on mild pain present on $1^{\text {st }}$ day in incision closed with vicryl suture material over incision closed with $\mathrm{N}$ Butyl 2 cyanoacrylate. There was statistically no significant on experience of pain between both groups on $3^{\text {rd }}$ day, $5^{\text {th }}$ day and $7^{\text {th }}$ day.

The measurement of pain and wound dehiscence measured on $1^{\text {st }}, 3^{\text {nd }}, 5^{\text {th }}, 7^{\text {th }}$ day for all the patients and statistical analysis performed between both groups to find out the benefit. Based on this analysis, statistically significant score was obtained on comparing the mild pain between both groups on day one only. In all other score for pain on day 1 , day 3, day, day 5 and day 7 showed statistically no significance between the both groups. There was statistically significant score was obtained on presence of wound dehiscence between both groups on day land day 3, where presence of wound dehiscence was more in incision closed with $\mathrm{N}$ Butyl 2 cyanoacrylate than incision closed with vicryl suture. But, on $5^{\text {th }}, 7^{\text {th }}$ day there was statistically no significant difference in presence of wound dehiscence between groups.

$\mathrm{N}$ Butyl 2 cyanoacrylate has a minimal role in closure of intra oral mucosal incision. Further studies are needed to evaluate the tensile strength of material and long term effects of N Butyl 2 cyanoacrylate.

\section{References}

[1] Shahlakakoei, FahimehBaghaei, Shahriardabri, Masoudparirokh and sinakakooei. A comparative in vivo study of tissue reactions to four suturing materials. Iran Endod J 2010;5(2):69-73.

[2] Wallace WR, Maxwell GR, Cavalaris CJ. Comparison of polyglycolic acid suture to black . J Oral Surg.1970;28:739-46.

[3] Katz S, Izhar M, Mirelman d. Bacterial adherence to surgical sutures. A possible factor in suture induced infection. Ann Surg 1981;194:35-41.

[4] Kumar MS, Natta S, Shankar G, Krishna SH, Visalakshi D, Seshiah GV. Comparison between silk sutures and cyanoacrylate adhesive in human mucosa-A clinical and histological study. J Int Oral Health. 2013;5(5);95-100.

[5] Bhaskar SN, Frisch J. Use of cyanoacrylate adhesives in dentistry. J Am Dent Assoc 1968 ;77(4):831-837.

[6] Ellis DA, Shaikh A. The ideal tissue adhesive in facial plastic and reconstructive surgery. J Otolaryngol 1990;19(1):68-72. 


\section{International Journal of Science and Research (IJSR) \\ ISSN (Online): 2319-7064}

Index Copernicus Value (2015): 78.96 | Impact Factor (2015): 6.391

[7] Tse DT, Panje WR, Anderson RL. Cyanoacrylate adhesive used to stop CSF leaks during orbital surgery. Arch ophthalmol 1984;102(9):1337-39.

[8] Weselis IF, McNeill JI. Applicator for cyanoacrylate tissue adhesive. Ophthalmic surg. 1989;20(3);211-214.

[9] Fernandez PM, Marquez D, Bretana RMG. Use of NButyl-2-Cyanoacrylate in oral surgery: biological and clinical evaluation. Artif Organs. 2000;24:241-3.

[10] Idle MR, Monagham AM, Lamin SM, Grant SWJ. N Butyl 2 cyanoacrylate tissue adhesive as a haemostatic agent in a venous malformation of the mandible. $\mathrm{Br} \mathrm{J}$ Oral Maxillofac Surg. 2013;51:565-567.

[11] Holzheimer RG. Adverse events of sutures:possible interactions of biomaterials. Eur J Med Res 2006;10:521-526.

[12] Sametinal, NergizYilmaz, CevatNisbet, and TolgaGüvenç, Samsun. Biochemical and histopathological findings of N-Butyl-2- Cyanoacrylate in oral surgery: an experimental study. J Oral Surg Oral Med Oral Pathol Oral RadiolEndod. 2006; 102: e14e17.

[13] HowardBM, Eshraghi SR, Refai D. Octyl-cyanoacrylate skin adhesive is effective for wound closure in posterior spinal surgery without increased risk of wound complications. J Cli Neuro. 2014;125:137-142.

[14] Joshi AD, Saluja H. Mahindra U. RajshekharHalli. A Comparative Study: Efficacy of Tissue Glue and Sutures after Impacted Mandibular Third Molar Removal. J Maxillofac Oral Surg. 2011;10(4):310-315.

[15] Koranyi G, Seregard S, Kopp ED. Cut and paste: a no suture, small incision approach to pterygiumsurgery. $\mathrm{Br}$ J Ophthalmol. 2004;88(7):911-914.

[16] Morettineto RT, Mello I, Silveiramoretti AB, Carlos Roberto Colombo, Robazza, Alessandro Antônio Costa, Pereira.In vivo qualitative analysis of the biocompatibility of different cyanoacrylate-based adhesives. Braz Oral Res. 2008;22(1):43-7.

[17] Howell JM, Bresnahan KA, Stair TO, Dhindsa HS and Edwards BA. Comparison of effects of suture and cyanoacrylate tissue adhesive on bacterial counts in contaminated lacerations. Antimicrob Agents Chemother. 1995;39(2):559-560.

[18] Montanaro L, Arciola CL, CenniE, Ciapetti G, Savioli,F. Filippini, L.A. Barsanti. Cytotoxicity, blood compatibility and antimicrobial activity of two cyanoacrylate glues for surgical use. J Biomaterials. 2001;22:59-66.

[19] Giray CB, Atasever A, Durgun B, Araz K. Clinical and electron microscope comparison of silk sutures and nbutyl-2-cyanoacrylate in human mucosa. Australian Dental J. 1997;42(4):255-8.

[20] Taira BR, Singer AJ. An In-Vivo Study of the WoundBursting Strengths of Octyl-Cyanoacrylate, ButylCyanoacrylate, and Surgical Tape in Rats. J \Emerg Med. 2010; 38 (May): 546-550.

[21] Alonso FC, Jornet P L. Clinical-pathological study of the healing of wounds provoked on the dorso-lingual mucosa in 186 albino rats. J Otolaryngol Head Neck Surg January. 2007;136:1119-124.

[22] Ankitavastani, Anishamaria. Healing of Intraoral Wounds Closed Using Silk Sutures and Isoamyl 2Cyanoacrylate Glue: A Comparative Clinical. J Oral Maxillofac Surg. 2013;71:241-248.
[23] Gumuş, P. and Buduneli, E. Graft stabilization with cyanoacrylate decreases shrinkage of free gingival grafts. Australian Dental J.2014;59:57-64.

[24] Bresnahan K.A , John. M. Howell, Joseph Wisoreck Comparision of tensile strength of cyanoacrylate inclosure of lacerations V/s suture adhesive. J. Ann Emergency Med 1995 (5); 578-8

[25] Bhaskar S N, Frisch J, Leonard F. Application of a new chemical adhesive in periodontic and oral surgery. $\mathrm{J}$ OralSurg Oral Med Oral Pathol.1966;22(4):526-535.

[26] Javelet J,Torabinejad M, Danforth R. Isobutyl cyanoacrylate: A clinical and histologic comparison with sutures in closing mucosal incisions in monkeys. J Oral Surg Oral Med Oral Pathol. 1985;59(1):91-94.

[27] Mogensbessermann. Cyanoacrylate spray in the treatment of prolonged oral bleeding. Int $\mathrm{J}$ Oral surg. 1977;6(4):233-240.

[28] Bhaskar SN, Frisch J, Duane E. Cutright, Peter Margetis ,Walter Reed.Effect of butyl cyanoacrylate on the healing of extraction wounds. Oral Surg Oral Med Oral Pathol.1967;24(5):604-616.

[29] Cotton A, H Deramond, B Cortet, J P Lejeune, X Leclerc, $\mathrm{P}$ Chastanet and $\mathrm{J}$ Clarisse.Preoperative percutaneous injection of methyl methacrylate and Nbutyl cyanoacrylate in vertebral hemangiomas.Scandinavian J of Surg 2011;100:120124.

[30]Alan B. Leahey, John D. Gottsch, Walter J. Stark.Clinical Experience with N-butyl Cyanoacryiate (Nexacryl) Tissue Adhesive. Ophthalmology J. 1993 ;100:173-180.

[31] Cantasdemir M, Adaletli, D Cebi, F Kantarci, N.D Selcuk, F Numan.Emergency Endovascular Embolization of Traumatic Intrarenal Arterial Pseudoaneurysms with N-Butyl Cyanoacrylate. Clinical Radiology.2003;58:560-565.

[32] Kulkarni S, Dodwad V, Chava V.Healing of periodontal flaps when closed with silk sutures and N-butyl cyanoacrylate: A clinical and histological study.Indian J Dent Res 2007;18:72-7.

[33] Dalvi A A, Faria M M, Pinto AA. Non-suture closure of wound using cyanoacrylate. J Postgrad Med. 1986;32:97-100.

[34] Kutcher MJ, Ludlow JB, Allen D Samuelson, Tamara Campbel, Susan N Pusek. Evaluation of bioadhesive device for the management of aphthousulcers. J Am Dent Assoc. 2001;132:368-376.

[35] Chai BH, Kim BY, Huh JY, Lee SH. Cyanoacrylate adhesive for closing sinus membrane perforations during sinus lifts. J Craniomaxillofac Surg. 2006;34:505-509.

[36] Abhisheksoni, Narula R, kumar A, parmar M, sahore $\mathrm{M}$, Mohinderchandel. Comparing cyanoacrylate tissue adhesive and conventional subcutucular skin sutures for maxillofacial incision-A prospective randomized trial considering closure time, wound morbidity and cosmetic outcome. J Oral Maxillofac Surg. 2013;71:2152e1-2152e8.

[37] Snehasetrya, Rajshekharhalli, Anandshah, Gauravchhabaria, Tarunsingh. Comparative evaluation of efficacy of tissue glue and sutures after surgical removal of impacted mandibular third molars. A 
prospectivecontrolled clinical study. Oral Surg Oral Med Oral Pathol. 2015;27:183-188.

[38] Cavalris CJ - Comparison of polyglycolicacidsuture to black silk, chromic and plain catgut inhuman oral tissues. J. OraI surgery. 2006;738-739;970.

[39] Ghoreishian M, Gheisari R, Fayazi M. Tissue adhesive and suturing for closure of the surgical wound after removal of impacted mandibular third molars: A comparative study. J Oral Surg Oral Med Oral Pathol Oral Radiol Endod 2009;108:e14-e16.

[40] Hasan Z, Gangopadhaya AN, Gupta DK, Srivastava P and. Sharma SP. Sutureless Skin Closure with Isoamyl 2-Cyanoacrylate in Pediatric Day-Care Surgery. Pediatric Surgery International 2009;25:1123-1125.

[41] Knott PD, Zias JE, Banbury J, Djohan R, Yetman RJ, Papay F. A comparison of dermabond tissue adhesive and suture in primary repair of congenital cleft lip. Annals of Plastic Surgery. 2007;58(2):121-125.

[42] Jehangirnezhad M; Semilunar coronally repositioned flap for the treatment of gingival recession with and without tissue adhesives: a pilot study, J of dentistry, Tehran university of medical sciences, Tehran. Iran J. 2006;3(1):25-27.

[43] Quin. J.V, Drzewiecki.A, Li.M et al - Arandomized controlled trial comparing tissueadhesive with suturing in the repair of paediatric facial lacerations. Ann Emerg Medicine. 1993;22 (7);1130-5.

[44] Toriumi DM, Raslan WF, Friedman M, Tardy ME.Histotoxicity of cyanoacrylate tissue adhesives. A comparative study. Arch Otolaryngol Head and Neck Surg. 1990;116(5):546-50.

[45] Sybelesaska, Ana Maria Minarelli Gaspar, Eduardo Hochuli-Vieira. Cyanoacrylate adhesives for the synthesis of soft tissue. An. Bras. Dermatol. 2009;84:215-220.

[46] Hesham. S. Khalil, Mohammad A. Elshall, Yazeed AlHarbi, Saeed Al-Asmar, Mohammad Al-Wadee. Healing of oral surgical wounds using 3/0 silk suture and n-butyl cyanoacrylate tissue adhesive. Egyptian dental Journal .2009;55:2607.

[47] Srinivasan S, Dollin M, McAllum P, Berger Y, Rootman DS, SlomovicAR.Fibrin glue versus sutures for attaching the conjunctivalautograft in pterygiumsurgery: a prospective observermasked clinical trial. Br J Ophthalmol2009;93(2):215-218.

[48] Schmeissner H, Galil HJ, Lundie MJ, Kaufmann JC. The histotoxicityoc cyanoacrylates. A systemic review. Neuroradiology. 1985;26(2):279-291.

[49] Harper MC and Ralston M, "Isobutyl 2-cyanoacrylate as a osseousadhesive in the repair of osteochondral fractures," JBiorned. Muter Res. 1983;17:167-177.

[50] Mehta MJ, Shah KH, Bhatt RG. Osteosynthesis of mandibular fractures with $\mathrm{N}$ butyl 2 cyanoacrylate: a pilot study. J Oral Maxillofac Surg. 1987;45(5):393396.

[51] Rice RM, Hegyeli AF, Gourlay SJ, Wade CWR, Dillion JG, Jaffe H, and Kulkarni RK, "Biocompatibility testing of polymers: In vitro studies with in vivo correlation," J Biomed Mate. Res. 1978; 12:43-54. 